\title{
Scalability and robustness of business models for sustainability: A simulation experiment
}

DOI:

10.1016/j.jclepro.2017.09.023

\section{Document Version}

Accepted author manuscript

Link to publication record in Manchester Research Explorer

\section{Citation for published version (APA):}

Taeuscher, K., \& Abdelkafi, N. (2018). Scalability and robustness of business models for sustainability: A simulation experiment. Journal of Cleaner Production, 170(1), 654-664.

https://doi.org/10.1016/j.jclepro.2017.09.023

\section{Published in:}

Journal of Cleaner Production

\section{Citing this paper}

Please note that where the full-text provided on Manchester Research Explorer is the Author Accepted Manuscript or Proof version this may differ from the final Published version. If citing, it is advised that you check and use the publisher's definitive version.

\section{General rights}

Copyright and moral rights for the publications made accessible in the Research Explorer are retained by the authors and/or other copyright owners and it is a condition of accessing publications that users recognise and abide by the legal requirements associated with these rights.

\section{Takedown policy}

If you believe that this document breaches copyright please refer to the University of Manchester's Takedown Procedures [http://man.ac.uk/04Y6Bo] or contact uml.scholarlycommunications@manchester.ac.uk providing relevant details, so we can investigate your claim.

\section{OPEN ACCESS}




\title{
Scalability and Robustness of Business Models for Sustainability: A Simulation Experiment
}

\author{
Karl Täuscher \\ Strategy Innovation and Sustainability \\ Alliance Manchester Business School at University of Manchester \\ Karl.Taeuscher@manchester.ac.uk \\ Nizar Abdelkafi \\ Business Models: Engineering and Innovation \\ Fraunhofer Center for International Management and Knowledge Economy \\ Leipzig, Germany
}

\section{Citation:}

Täuscher, Karl \& Abdelkafi, Nizar (2018): Scalability and robustness of business models for sustainability: A simulation experiment. Journal of Cleaner Production, 170, p. 654-664.

DOI: $\underline{\text { https://doi.org/10.1016/j.jclepro.2017.09.023 }}$

The publisher's post-print is available at:

https://www.sciencedirect.com/science/article/pii/S0959652617320115?via\%3Dihub 


\title{
Scalability and Robustness of Business Models for Sustainability: A Simulation Experiment
}

\begin{abstract}
An increasing number of entrepreneurial ventures aim at developing viable business models for solving societal or ecological challenges. Such business models for sustainability (BMfS) build on reinforcing mechanisms of value creation and capture that allow to simultaneously achieve financial and sustainability objectives. To date, we do not know much about the successful design of such business models for new markets with highly uncertain dynamics. Hence, this research aims at advancing the understanding about two key characteristics of successful BMfS - scalability and robustness - and their impact on performance of entrepreneurial BMfS in uncertain environments. Toward this aim, it uses simulation modelling of an entrepreneurial BMfS under different future scenarios. The simulation represents the case of Coursera, an entrepreneurial venture with the social mission of making high-quality education globally accessible through Massive Open Online Courses (MOOCs). Rooted in the literature on business models (for sustainability), innovation adoption and System Dynamics, the simulation model integrates the four value dimensions of BMfS and allows testing different hypotheses about its sustainable performance. The simulation experiments show that the business model is scalable, but not sustainable in a scenario of high competition. We discuss the implications of the simulation results for the effective design of entrepreneurial BMfS.
\end{abstract}

\section{Keywords}

Business Model for Sustainability (BMfS); Entrepreneurial business models; Business model analysis; Simulation modelling; System dynamics; innovation diffusion; MOOC 


\section{Introduction}

An increasing number of entrepreneurs aims at developing business models that are not only financially viable, but also contribute positively to society and the natural environment (Schaltegger et al., 2016a). Among others, this phenomenon has been discussed under the labels of sustainability business models (Stubbs and Cocklin, 2008), business models for sustainability (Schaltegger et al., 2012), business models for sustainable innovation (Boons and Lüdeke-Freund, 2013), or sustainable business models (Bocken et al., 2014). These concepts commonly refer to business models that integrate a social or ecological value proposition at the core of their value creation logic, and therefore go beyond adding sustainable practices to an otherwise unsustainable business model (Schaltegger et al., 2016a).

This paper focuses on BMfS developed by entrepreneurial ventures. Entrepreneurship has been identified is a potential panacea for a variety of today's most important social challenges (Brugmann and Prahalad, 2008, Hall et al., 2010, 2010; Hart and Milstein; Tilley and Young, 2006). Especially in early stages of an industry's sustainability transformation, entrepreneurial ventures are more likely to pursue sustainability-related opportunities than incumbents (Hockerts and Wüstenhagen, 2010). Yet, these transformational phases in general lead to high uncertainty regarding market adoption or the availability of critical resources (Bocken, 2015; Hall et al., 2010).

BMfS that cannot sufficiently deal with potentially unfavorable market conditions are likely to fail. Consider the case of Better Place that aimed at implementing an innovative business model for its battery swapping services in the area of electric mobility (e.g. Noel and Sovacool, 2016). Despite being externally funded with nearly a billion USD, the venture ceased operations less than three years after foundation and therefore never succeed in creating any ecological or economic value. Among others, the firm struggled with resistance of critical partners and low adoption of its electric cars in the market. Since the business model required Better Place to rapidly expand its capital-intensive 
infrastructure, it proved incapable to deal with these unexpected conditions (Noel and Sovacool, 2016). This example illustrates that the assessment of BMfS should draw on more criteria than their innovativeness and potential sustainability impact. In particular, business models need to be also robust under a variety of external conditions (Bouwman et al., 2008b; Casadesus-Masanell and Ricart, 2011). Towards the aim of a more holistic analysis of BMfS, this research aims to contribute to the understanding of successful design of BMfS by answering two questions: What characterizes successful design of entrepreneurial BMfS in uncertain environments? How can the scalability and robustness of an entrepreneurial BMfS be analyzed dynamically?

We approach these questions by analyzing the design of BMfS through conceptual modelling and simulation experiments. The research builds an integrative simulation model for an entrepreneurial BMfS by representing the causal links between its value dimensions and elements graphically and mathematically. The model aims to advance the understanding about the dynamics and interdependencies between the success measures of such business models and allows experimenting with their performance dynamics under different future scenarios.

As a context for this work, we focus on Massive Open Online Courses (MOOCs). MOOCs are considered a sustainable innovation with high potential for contributing towards a highquality education that is accessible and affordable for people around the world (Hoyt, 2014; Leckart, 2012; Pappano, 2012; Porter, 2015b). However, the entrepreneurial ventures that offer MOOCs are yet to prove the viability of their business models from a financial viewpoint. The research simulates the business model of Coursera, the largest MOOC platform at present, to derive insights into its scalability and robustness. Based on the findings in this context, we then discuss broader implications for the successful design of entrepreneurial BMfS. 


\section{Theoretical background}

\subsection{Business models for sustainability (BMfS)}

A business model describes a firm's logic of creating, delivering and capturing value (Teece, 2010). While the mainstream business model literature provides many understandings of the concept, many researchers agree that the business model concept integrates (at least) a customer dimension, a value creation dimension and a value capture dimension (Abdelkafi et al., 2013; Johnson et al., 2008; Osterwalder and Pigneur, 2010; Teece, 2010). The customer dimension defines the target customers and how the firm aims to provide value to them (Osterwalder and Pigneur, 2010). The value creation dimension considers how and with whom the firm creates the value proposition (Johnson et al., 2008). The value capture dimension (Abdelkafi et al., 2013) or financial dimension (Osterwalder, 2004) considers the business from a financial perspective. It includes decisions on how the firm transforms the created value into revenue streams and ultimately profits (Chesbrough and Rosenbloom, 2002). The business model differs from other units of analysis by its holistic perspective that spans organizational boundaries and different systems levels (Zott et al., 2011).

Sustainability researchers have increasingly adopted the business model as unit of analysis to describe and communicate the logic of sustainability-oriented organizations (Adams et al., 2016; Arevalo et al., 2011; Bocken et al., 2014; Schaltegger et al., 2016a). This paper follows the definition of BMfS as formulated by Schaltegger et al. (2016a, p.6): "A business model for sustainability helps describing, analyzing, managing, and communicating (i) a company's sustainable value proposition to its customers, and all other stakeholders, (ii) how it creates and delivers this value, (iii) and how it captures economic value while maintaining or regenerating natural, social, and economic capital beyond its organizational boundaries". The definition does not distinguish BMfS based on the firm's hierarchy of motives or specific types of sustainable value propositions. As such, it includes for-profit and non-profit organizations. Moreover, it explicitly defines BMfS 
based on their 'sustainable value proposition' and the consequences of business model decisions on the firm's overall impact at the economical, natural and societal level. In fact, some researchers propose that BMfS incorporate an additional dimension that represents the value created to the natural or societal environment (Abdelkafi and Täuscher, 2016). The understanding is in line with other conceptualizations of BMfS (Bocken et al., 2014; Boons and Lüdeke-Freund, 2013).

Business model design and management has further attracted the interest from the field of sustainable entrepreneurship (Schaltegger et al., 2016b). Sustainable entrepreneurship generally focuses on commercial organizations aiming to solve societal and environmental problems (Schaltegger and Wagner, 2011). Extant research has identified innovative business models to create societal wealth (Sánchez and Ricart, 2010; Seelos, 2010; Thompson and MacMillan, 2010) and ecological value (Jolink and Niesten, 2015), investigated how entrepreneurial motives and values influence their business models (Parrish, 2010) and studied how venture capital can enable and support the development of BMfS (Bocken, 2015). Yet, there is a dearth of knowledge on the success characteristics and intended outcomes of different configurations of entrepreneurial BMfS.

\subsection{Characteristics and outcomes of effective BMfS}

There is no common understanding of the outcomes of effective business model design. Mainstream business model literature focuses primarily on the consequences or outcomes of 'total value creation' (Amit and Zott, 2001), the ability to create a competitive advantage (Christensen, 2001; Teece, 2010) Teece, 2010) and superior firm performance (Zott and Amit, 2007, 2008; Zott et al., 2011), or the ability to create and capture value from technology (Chesbrough and Rosenbloom, 2002; Hedman and Kalling, 2003). BMfS further pursue the outcome of environmental or societal value (Abdelkafi and Täuscher, 2016; Schaltegger et al., 2016a). This outcome is in line with a triple-bottom-line (TBL) approach to performance measurement, as proposed by several sustainability researchers 
(Bocken et al., 2014; Elkington, 1999; Stubbs and Cocklin, 2008). Wells (2016) suggests that organizational stability might be another intended outcome of BMfS, since frequent organizational changes might incur important social and environmental costs (Wells, 2016). As a consequence, analyzing BMfS requires integrating several performance outcomes holistically.

Similarly, there are several understandings about the characteristics of effective business models. Casadesus-Masanell and Ricart (2011) argue that business models are effective, if they fit to the firm's strategic objectives, build on consistent elements that reinforce each other and enable scalability, and exhibit robustness against external threats. While many researchers agree on the necessity of consistent and reinforcing design elements (Amit and Zott, 2012; Demil and Lecocq, 2010; Demil et al., 2015; Hamel, 2002), there is not much conceptual knowledge available regarding the design elements supporting robustness of business models (Täuscher and Abdelkafi, 2015). Casadesus-Masanell and Ricart (2007, 2010, 2011) consider robustness as the business model's ability to fend off external threats. Bouwman et al. (2008a) consider robustness in a broader context and define as "the ability to cope with changes in the business environment [...]. Typical examples of external influences are changes in user requirements, regulatory changes, emerging new target groups and changing scale of operation, the application of a different revenue model or the incorporation of a new technology" (Bouwman et al. 2008a, p. 132). Scholars have particularly focused on the technological, market and regulatory risks that affect the robustness of business models (Bouwman et al., 2008a; Bouwman et al., 2008b; Reuver et al., 2009). Hence, analyzing the effectiveness of business models requires both a conceptual understanding about their feedback loop structure (Casadesus-Masanell and Ricart, 2011) as well as an understanding about their behavior under different future scenarios (Reuver et al., 2013).

Assessing the scalability and robustness of BMfS is even more challenging since they need to connect the sustainable and customer value proposition in a scalable and reinforcing 
manner to potentially overcome or at least substantially shift the trade-off between sustainability and financial performance (Abdelkafi and Täuscher, 2016).

\section{Modelling an Entrepreneurial Business Model for Sustainability}

\subsection{Modelling paradigm and approach}

We choose System Dynamics (SD) as a suited paradigm to model and simulate complex and dynamic systems. Principles of SD are closely aligned with the nature of the business model concept. Thus, recent research on BMfS has made the case for an SD-based approach to conceptualizing BMfS (Abdelkafi and Täuscher, 2016) and has developed a conceptual model of key elements and their causal connections of BMfS. The modeling approach aims at advancing the conceptual model by applying it in the simulation model.

The modelling approach builds on the five steps process developed by (Sterman, 2000). First, we articulate the model purpose. Second, we develop dynamic hypotheses, formulate the assumptions related to the modelled system, and integrate them visually into a conceptual model. Third, we transform the conceptual model into a quantitative stock-andflow model that represents the formulated assumptions as a system of mathematical equations. Fourth, we test the structural and behavioral validity of the model and conduct the simulation experiments. Finally, we derive implications about the potential performance paths of the business model and assess its overall robustness.

\subsection{Model purpose}

The developed simulation model aims at theoretically representing the core causal structure of a BMfS, simulating its performance in the future and experimentally testing its robustness to different changes in the business model's environment. While the model is guided by the conceptual model of Abdelkafi and Täuscher (2016) and aims at representing a structure of an entrepreneurial BMfS, it is calibrated to the case of Coursera. 
Coursera is a platform provider for Massive Open Online Courses (MOOCs). Founded by the two Stanford professors Andrew Ng and Daphne Koller in 2012, the venture aims to "provide universal access to the world's best education" (coursera.org). The company partners with universities to provide their courses digitally via its online platform to learners around the world. In particular, the entrepreneurs aim to solve two highly pressing social issues. One the one hand, the cost of education in the US - their country of residence - continued to increase every year, with the price for a four-year degree of up to $\$ 160.000$. As a consequence, young adults increasingly face large debts when leaving their academic careers (Casadesus-Masanell and Kim, 2013). On a global level, the founders recognized the large inequalities in access to high-quality education as one of the biggest social challenges. With their engineering background, the founders recognized the social opportunity to digitize the educational content of the world's best universities and provide learners around the world free access to this content via an efficient web-based and mobile platform. Co-Founder Koller explained the rational, that "most people will never have access to a Princeton, Stanford, Cal Tech class. But now, if you wake up tomorrow morning and you decide to take a Cal Tech class, [...] you can just sign up for one and it's free." (PBS Newshour, 2013).

Coursera's business model is characterized by three key patterns. First, the company uses a Freemium model, emphasizing that its courses will always be freely accessible. To generate revenues, it offers complementary products and services such as verified certificates. Since 2015, the company further offers pre-defined course bundles on topics like "Data Science" - so-called Specializations -that include a series of related courses, a final project, and controlled exams. To receive a certified degree for in these specifications, learners have to pay a tuition fee. Second, the company outsources the course creation and teaching to leading universities that enter long-term partnerships with Coursera. These universities expect primarily branding and reputation benefits from participation (Porter, 2015a). As a financial incentive, the company shares 6 to $15 \%$ of course revenues with the university that created the course. Third, the company itself can be described as a 
technology firm and focuses on the key activities of engineering the technological platform with sophisticated search and recommender systems and community development for expanding the number of users and partner universities (Casadesus-Masanell and Kim, 2013). The business model therefore offers its free users and paying customers a selfcustomized learning experience on the basis of the educational content created by partner universities and the learner community and technological features provided by Coursera.

We selected the specific case for several reasons. Coursera represents an entrepreneurial venture - founded by academics - that has a strong social mission, but simultaneously pursues financial objectives. In fact, this hybrid focus can be seen both as an enabler and consequence of the business model. Operating Coursera's business model in the start-up and early growth phase required cash from external funding sources. The decision to use venture capital for growth funding, in turn, requires Coursera to aim for building a scalable business model that allows capturing profits in the long run. We further selected the case for the innovativeness and societal impact potential of the product and the business model. The context of MOOCs and online learning has been identified as an area with high potential for contributing to a more equal and accessible system of higher education (Porter, 2015a). Due to the high uncertainty about future market adoption of MOOCs and the competitive dynamics (Porter, 2015b), it provides an ideal case for the purpose of this research. In fact, research and the public eye have pointed out that the future of MOOCs strongly depends on whether their providers they can develop a viable business model (Fischer, 2014; Porter, 2015a). To date, there is no common understanding about whether Coursera's business model is viable in the long run and whether it will allow the venture after it ceases to receive venture capital funding. (Porter, 2015a).

\subsection{Conceptual model and dynamic hypotheses}

The performance of innovative business models is influenced by a complex set of causes and consequences (Täuscher and Chafac, 2016). Following the specific purpose of this 
research, we focus on the causes and consequences that have high relevance in regards to the research questions. Based on the conceptual model proposed by Abdelkafi and Täuscher (2016), we start the dynamic hypotheses building by identifying whether and how Coursera's business model generates a reinforcing feedback loop that strengthens the value to customers, the value to the environment, the captured value, and the value creation (capacity). For the BMfS of Coursera, several reinforcing effects are in place that drive its financial and sustainability performance. Abdelkafi and Täuscher (2016) suggest that the four value dimensions are connected via one or more of five business case drivers proposed by Schaltegger et al. (2012): reputation, sales and margins, employer attractiveness, cost reduction, or risk reduction. The business case drivers should provide the rational that causally connects the societal value creation to the firm's value capture. (Abdelkafi and Täuscher, 2016).

To identify the link between the societal value creation and the value capture dimension, we need to define a measure for Coursera's societal value creation. As for similar societal value propositions, there exists great uncertainty about how to represent, measure and assess the societal value created by MOOCs (Fischer, 2014). Since the individually perceived societal value strongly depends on the person of the learner (Kizilcec and Schneider, 2015), her motivations (Hew and Cheung, 2014), and learning context (Barak et al., 2016), operationalizing the societal value based on perceptions is highly complex. For simplicity, we use the number of learners that use the free offering of the platform ('users') and the accumulated amount of courses taken by these learners ('total course enrollments') as proxies for the societal value creation. These metrics build on the assumptions that Coursera creates societal value by enabling users to gain free access to high-quality education and that the social beneficiaries (the free learners) receive more societal value the more courses they take. This understanding is in line with the venture's social mission.

Coursera's societal value proposition of free course enrollments enhances its value capture potential via the business case driver of (increased) sales and margins. Freemium business 
models generally build on the expectation of converting a fraction of the free users into paying customers (Wagner et al., 2014). The more free users the venture serves, the higher is the pool of potentially paying customers. This causal relation is further strengthened by the assumption that an increased network size of free users acts as a signal for content quality and acceptance of Coursera's among employers and therefore potentially increases sales and margins. The number of free users increases the number of paying customers, which leads to an increase in captured value (revenues, profit), which increases the value creation capacity (partners, course selection), that ultimately reinforces the societal value proposition. The reinforcing feedback loop in the right-hand side of figure 1 therefore encompasses all four dimensions of BMfS. The right-hand side of the causal loop diagram further depicts that the business model simultaneously creates a balancing feedback loop from the increased costs of serving free users. Every free user therefore equally increases the societal value creation, but also incurs costs to the company when free users watch video lectures and other material online.

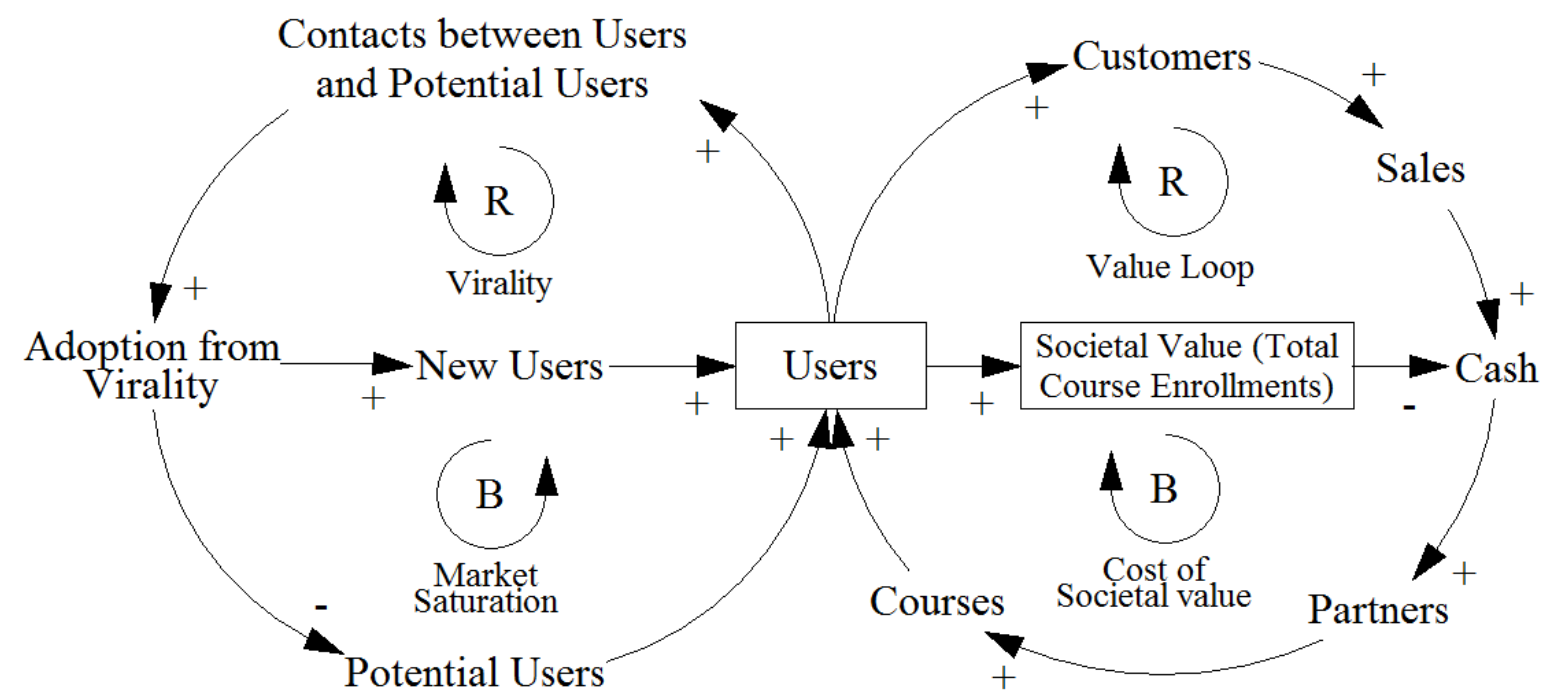

Figure 1: Reinforcing feedback loops generated by Coursera's business model

The left-hand side of figure 1 additionally represents the causal structure of the innovation adoption model as formulated by Bass (Bass, 1969) and adopted in a variety of adoption studies. Coursera's business model strongly builds on the viral adoption of potential users 
that learn about the venture's offering from users (Casadesus-Masanell and Kim, 2013). Hence, the reinforcing feedback loop of viral user adoption is an essential driver of the firm's user adoption. Adoption models in system dynamics further include a balancing loop of market saturation that depicts the effect of decreasing contacts between users and nonusers as the number of non-users decreases over time.

Feedback loops are identified as a key determinant of complex systems and a major antecedent of non-linear system behavior (Ford, 1999; Morecroft, 2015; Sterman, 2000). SD scholars therefore study the behavior of complex systems with particular feedback loop combinations to identify generic behavioral patterns. Rather than forecasting the exact performance of a system, understanding the feedback loop structure of a system allows anticipating its dynamic performance (Forrester, 1971; Forrester, 1976; Senge, 1994). In turn, observing a particular behavior of a system can also provide information about its feedback loop structure (Sterman, 2000). In particular, a system that exhibits an exponential growth trajectory is an indicator that the system is dominated by at least one strong reinforcing feedback loop. System that are characterized by multiple feedback loops with strong impact on the model often show more complex behavioral patterns. These include S-shaped growth curves or a pattern of 'Overshoot and Collapse', where a critical resource is fueling a rapid growth phase in a non-sustainable manner and eventually causes the system to collapse after it has been depleted completely. Testing the impact of the reinforcing feedback loops allows us making an assessment about the scalability of the business model. We therefore formulate hypothesis 1 in regards to the performance trajectory of the societal value creation:

H1: Coursera's societal value creation follows an exponential growth trajectory over the medium-term horizon.

Coursera's business model operates in a new and dynamic market in which the development of user adoption or competitive dynamics is difficult to predict. As such, an 
effective business model should be robust under different environmental conditions. To test the robustness of the overall business model, we individually assess the robustness of the sustainability and the financial performance for different scenarios. Hence, we formulate hypothesis 2 and 3 in the following manner:

H2: The sustainability performance of Coursera's business model is robust under different future scenarios.

H3: The financial performance of Coursera's business model is robust under different future scenarios.

The subsequent simulation modelling process aims at representing the conceptual model to allow testing the hypotheses.

\subsection{Simulation model}

The simulation modelling follows the qualitative and mathematical guidelines as proposed by Sterman (2000). Sterman (2001) provides a management-oriented introduction into the notation of stock-and-flow simulation models and the complementary mathematical equation modelling. The simulation model consists of several modules that are linked together via the value loop as depicted in figure 1. The user adoption module and the global internet penetration module are derived from previous simulation models (e.g. (Oliva et al., 2003; Täuscher and Chafac, 2016). We develop entirely new modules to represent the module for value creation that contains the key stocks of 'partner universities', 'course selection', and 'employees'. In total, the value creation module contains 22 variables that primarily aim to model the cost structure in dependence of user adoption and platform usage as well as modelling the in course selection. We further develop a module for value capture that integrates the different cost drivers and revenue streams from other modules into the variable 'operating income'. The value capture module further depicts the venture's cash as a stock that represents the running operational 
cash flows as well as the cash received from venture capital. To account for the venture capital financing, we introduce a stock that depicts the 'created financial value' as a measure of the accumulated cash minus the received venture capital funding. This metric should provide an additional metric for the financial performance of the business model. Finally, we build a module for the customer dimension. The module aims at determining the annual conversion rate from users to customers as a consequence of the relative satisfaction of free users with Coursera's offering. It builds on two dynamic effects: the relative price advantage against competitions and the effect from increase in course selection. Both effects utilize mathematical models and empirical data from research in the area of MOOCs and markets for digital content products (Brynjolfsson et al., 2011; Doerr et al., 2010; Huanhuan and $\mathrm{Xu}, 2015$; Smith et al., 2002). The full stock-and-flow simulation model is depicted in appendix A.

\subsection{Data gathering and model validation}

The model is calibrated with data from the venture's foundation in 2012 to mid-2016. Since the company is privately owned, it is not required to publish financial statements. Hence, we had to gather data from multiple sources, including a case study (CasadesusMasanell and Kim, 2013), published research articles (Hew and Cheung, 2014; Hoxby, 2014; Hoyt, 2014; Porter, 2015a), new articles, Coursera's press releases as well as data from data services and industry reports for the estimation of general parameter values.

To test the validity of the simulation model, we follow established approaches from SD as described in the literature (Barlas, 1996; Sterman, 2000). Besides a variety of behavioral model tests, we further conduct a workshop with business model scholars to test the structural validity of the model. To test the model's reliability to represent the performance trajectory of Coursera until 2016, we compared the simulated trajectory with the infrequent data points identified in multiple sources for the number of users and offered courses. The external dynamics represented in the simulation model allow higher fitting performance of 
the model due to the smoothness of the trajectory and the data quality. Figure 2 graphically the differences between the simulated and the actual trajectories for the internet population growth as well as Coursera's number of users and courses.

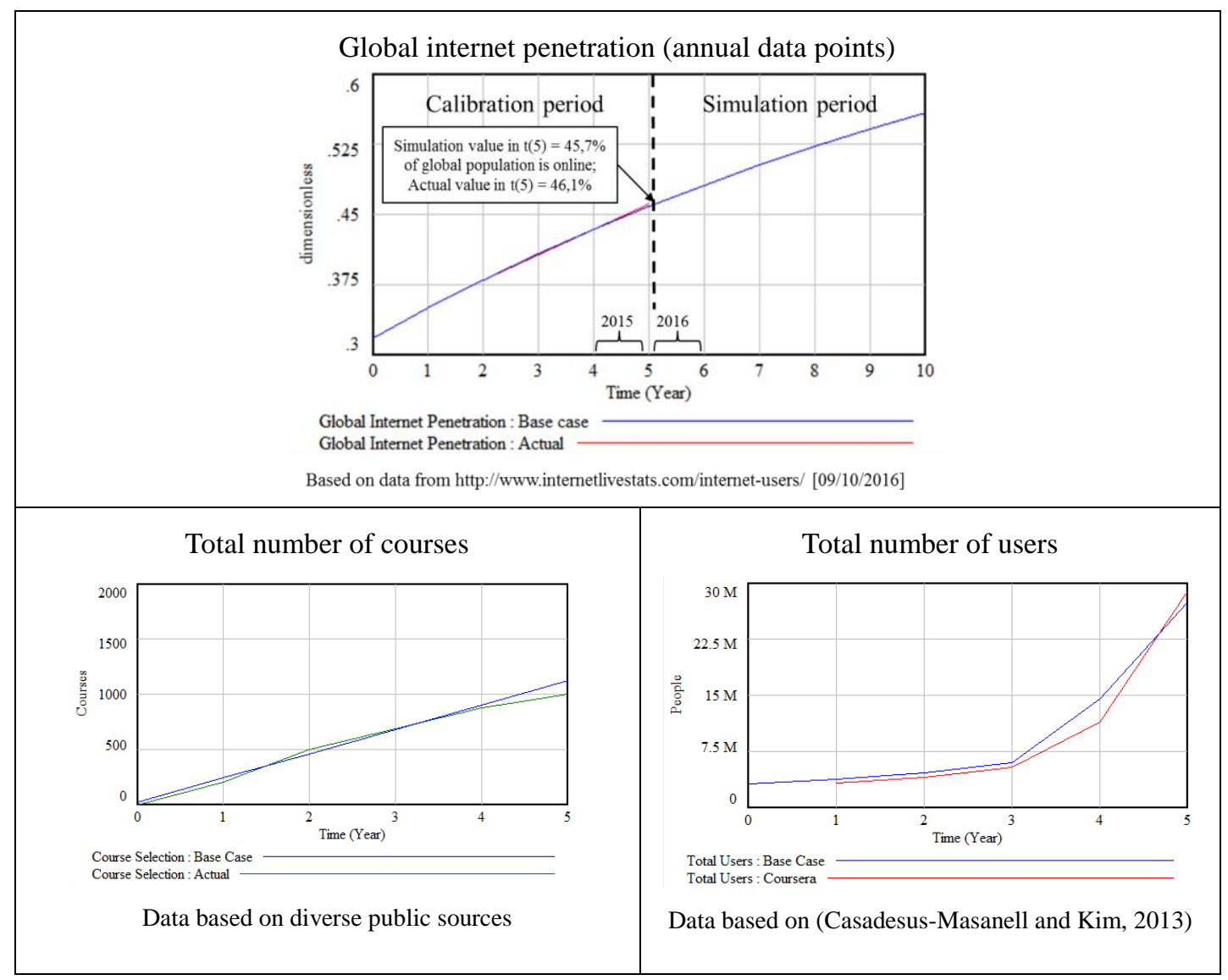

Figure 2: Comparison of the simulated and actual data for three variables

\section{Simulation results and discussion}

\subsection{Base case simulation of BMfS}

To test the hypothesis 1 , we run a base case simulation that represents the venture's performance with the best estimates for each of the parameter values. Figure 3 shows three measures that represent the value dimensions of societal value creation (number of enrollments), value creation capacity (course selection), and value capture (operating income) from the venture's first (2012) to the tenths year of operations (2012). 


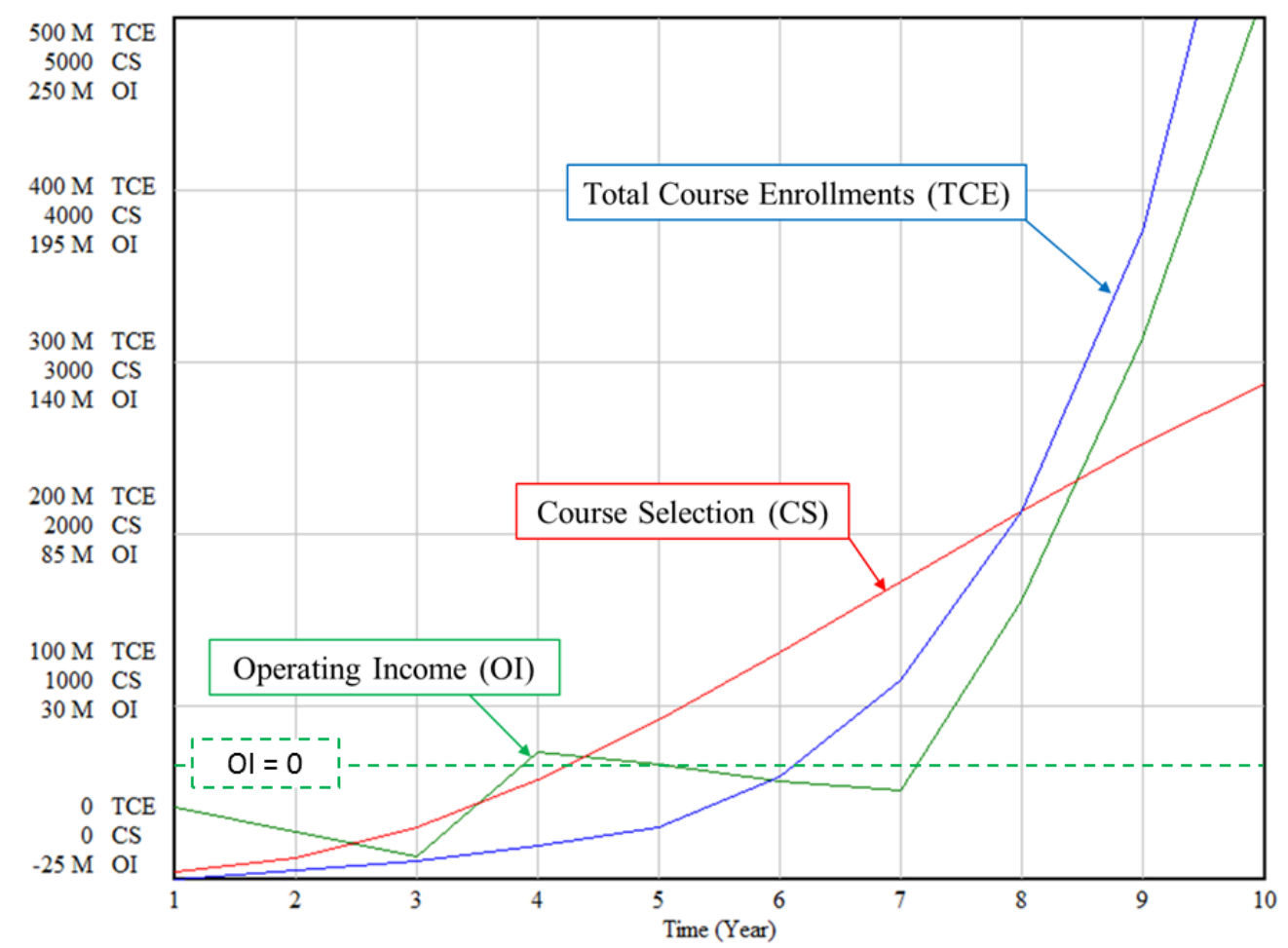

Figure 3: Simulated growth trajectory for Coursera's base case assumptions

The figure and the related data (appendix B) allow analysing the trajectory of the firm's societal value creation. The number of student enrollments, representing the created societal value, follows an exponential growth curve and therefore confirms hypothesis 1 . The exponential growth pattern suggests that the societal value creation is driven by a strong reinforcing feedback loop and therefore highly scalable.

The trajectory of the financial performance - represented as the operating income follows a more complex pattern over the first years. Except for a slightly positive value in period 4 , the model suggests that the venture only starts generating a positive operating income after period 7. This specific pattern is a consequence of different underlying effects. First, the company only starts to generate substantial revenue in the third period. Interestingly, the operating income even declines in the subsequent periods of the model (representing the years 2013 to 2017). This can be explained by the structure of the company's key cost drivers. The company's overhead costs are determined by the venture's 
number of employees. The employment growth is modelled from available data points that suggest that the number of employees initially grew at a faster rate than in the later periods. In addition, the costs for initiating new partnerships with universities and the annual cost for managing a course (e.g. updating course information) follow an almost linear growth curve and therefore affect the operating income over-proportionally in the first periods when revenue is small. In fact, the growth curve for the number course selection (amount of courses offered) is also slightly S-shaped. Besides, the 'costs per course per user'

(primarily costs for hosting the consumed videos) grow proportionally with the number of course enrollments and therefore also affect the firm's operating income strongly when a large amount of users is taking courses, but only few customers are paying for certificates. It is noteworthy that we cannot test the validity of the financial performance since the venture does not publish any data in regards to its financial performance.

\subsection{Simulation of BMfS under three scenarios}

To test the hypotheses 2 and 3, we develop three scenarios that each focuses on a different threat. As identified in the literature review on business models, threats to a business model can primarily arise from unexpected market developments, competitive dynamics, the firm's operational efficiency as well as changes in the regulatory or technological environment. While we do not consider changing regulations or technologies, we build a scenario for each of the three areas of market, competition and operations:

- Low market adoption: In the scenario, a smaller share of global internet users is potentially interested in online learning, total internet penetration grows at a slower rate, and potential users that come in contact with users are much less likely to adopt the platform.

- High competition: In the scenario, new competitors enter the market with average course prices below those of Coursera, affecting the effect from relative price advantage and therefore the conversion rate from users to customers. Since online learners can simultaneously purchase courses and degrees from different learning platforms, the 
increase in competition further decreases the purchase frequency of Coursera's paying customers. The increased competition further leads to a decline in Coursera's gross margins since competitors compete for leading universities by offering higher commission rates for exclusive partnerships.

- Low operational efficiency: In the scenario, the company incurs much higher variable costs per user per course (for hosting) and higher fixed costs per course for managing them on Coursera's website. Due to relatively low functionality of Coursera's platform and low efficiency of the marketing team, the company incurs significantly higher costs per user acquisition than in the base case scenario.

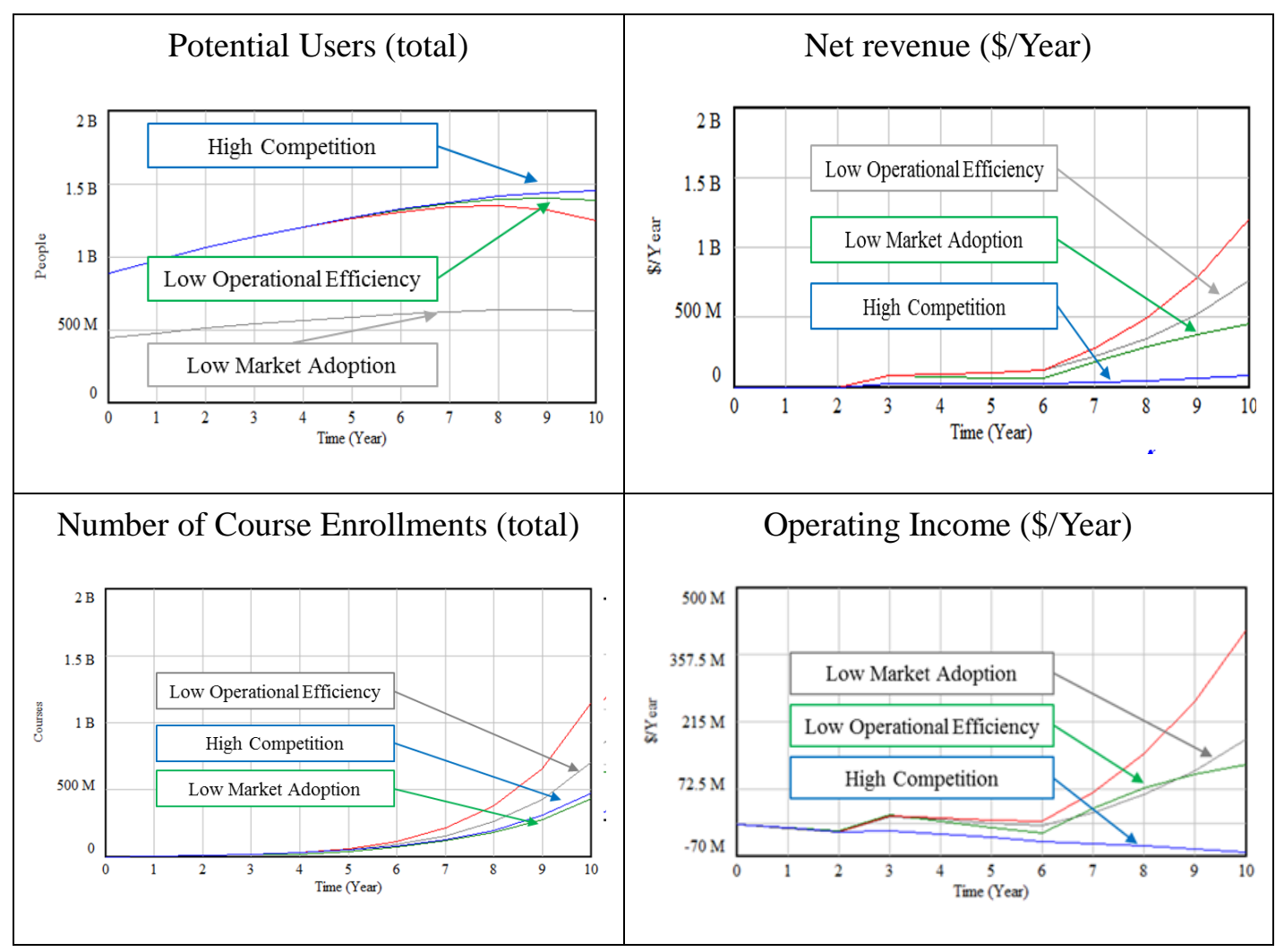

Figure 4: Performance metrics for baseline simulation and scenario-based experiments

Figure 4 shows the firm's financial and sustainability performance for the three developed scenarios of low market adoption, low operational efficiency and high competition. The growth curves suggest that the venture can grow its societal value exponentially despite 
unfavorable conditions, which confirms hypothesis 2. The different conditions do affect, however, the speed at which Coursera can scale the business and create the societal value.

Coursera's financial performance is, however, more sensitive to the environmental conditions. The simulation in the 'High Competition' scenario leads to a negative operating income in all simulated periods. In the scenario, the company would lose more money with every period. In the two other scenarios, the operating income becomes positive between period 7 and 8. However, the trajectory of the operating income in the 'Low Market Adoption' scenario already starts slowing down and is likely to balance around a threshold value over the subsequent periods. While the difference in financial performance between the 'Low Market Adoption' and 'Low Operational Efficiency' scenarios is marginal for the simulated time period, the spread will significantly increase in favor of the 'Low Market Adoption' scenario over every period. In this scenario, however, the lower amount of potential users (represented in the upper-left quadrant) limits the scalability of the societal value creation. In summary, we reject hypothesis 3 due to the business model's inability to lead to financial sustainability over all considered scenarios.

\subsection{Implications for effective design of BMfS}

The modelling process and the simulation experiments allowed the generation of new insights into how particular business model decisions affect the design characteristics (scalability and robustness) and performance outcomes (financial performance and societal value creation) of entrepreneurial BMfS. First, the simulation emphasizes the importance of the selected target market on the scalability of the sustainable value proposition. In the case of Coursera, the large market of potential online learners allowed reinforcing user adoption over the simulated period. In fact, the exponential trajectory of user adoption reveals the small balancing effect from the market saturation feedback loop. This is in line with the empirical observation that the market for MOOCs has allowed several competitors to grow their user base at a rapid pace (Porter, 2015a). Second, trajectory of user adoption is sensitive to the on the contact rate between existing and potential users, and the 
likelihood that potential users adopt the innovation (Bass, 1969). Literature on the diffusion of innovations suggests that these rates are higher for innovations that fulfill five criteria: observability within the social system, triability, compatibility, low complexity, and the existence of a competitive advantage against prior solutions (Rogers, 2003). Existing research supports the idea that MOOCs are aligned with these criteria (Belleflamme and Jacqmin, 2016; Huanhuan and Xu, 2015; Porter, 2015b). Therefore, we propose that the diffusion characteristics of the firm's offered product strongly influences the scalability of the BMfS. Third, the simulation experiments have shown the complex relationship between the value creation model, the resulting cost structure, and the business model's scalability. We know from the literature that business models are more scalable, if they build on a multi-sided models that outsource activities with high costs, provide a selfcustomized value proposition to users, and enable the firm to flexibly adjust its value creation capacity through modular design (Stampfl et al., 2013; Zhang et al., 2015). Coursera's business model incorporates these patterns, as the platform partners with universities that are in charge of creating and teaching the courses as well as supervising the students. As such, Coursera has to incur only a small marginal cost for every additional user it serves. Since the overhead costs do not grow proportionally with an increase in the number of customers, there exists a strong incentive for the firm to rapidly grow its customer base to increase its profitability. The number of customers, in turn, is positively influenced by the number of overall users (given the Freemium model). Hence, the particular design of the business model provides a financially-driven incentive to rapidly expand the societal value proposition to more users.

\section{Conclusions and outlook}

The paper makes many contributions to the extant literature. First, it can be seen as a call for a more nuanced analysis of entrepreneurial BMfS. The case of Better Place has emphasized the biased perception of such business models, when the discussion is only focused on the business model's innovativeness and potential contribution to sustainability 
goals. To be successful, a BMfS needs to be sustainable itself. Especially in turbulent and uncertain environments, a key characteristic of successful BMfS is their robustness to changes in the environment. Second, the research demonstrates how an entrepreneurial venture can use a BMfS to improve its sustainability impact. As such, the simulation model confirms the conceptual assertion that effective BMfS generate a reinforcing feedback loop between the sustainable value creation and the firm's value capture (Abdelkafi and Täuscher, 2016) and that an effective business model design can overcome - or at least substantially shift - the perceived trade-off between financial and sustainability performance (Schaltegger and Synnestvedt, 2002). Designing such an effective BMfS therefore allows ventures to enter a virtuous circle of 'doing good' and 'doing well'. Third, the simulation model can serve future research as a platform for testing a variety of related questions and hypotheses. While the simulation model is calibrated to Coursera, its general feedback loop structure represents a generic entrepreneurial BMfS. Among others, future research can test the performance implications of potential changes of the business model. Also, the simulation model contributes to the design-oriented sustainability research by providing managers with a tool for low-cost business model experimentation. In particular, the simulation-based approach can be used as a management tool to stress-test the performance of a BMfS under different assumptions. Finally, the research contributes to the existing literature on sustainable entrepreneurship by integrating the business model with an innovation adoption perspective that opens up a new perspective on growth and performance trajectories of sustainability-oriented ventures.

This work is, however, not without limitations. The business model as a unit of analysis can be highly insightful; yet, its performance depends on a variety of factors within the firm, its ecosystem, and the larger socio-economic and technological environment. The simulation model has included key environmental aspects such as the global internet adoption, but is far from incorporating all influencing factors. The quantitative simulation results should therefore be considered as illustrative rather than predictive. Besides, the simulation model uses simple proxies for operationalizing societal value creation. Future 
research could combine the model with formal measurement approaches and indices developed within the sustainability management literature. Finally, the simulation model treats the BMfS as unchanged over the simulation period. In practice, entrepreneurs can frequently adapt and fine tune their business models to reflect unexpected changes in the environment or within the firm. As such, future research could additionally study whether certain design configurations of BMfS are more easily adaptable than others and how this influences the importance of business model robustness. As a consequence, researchers can use the BMfS simulation model as a platform to expand upon and combine it with other strategic and organizational perspectives on sustainability-oriented ventures.

\section{References}

Abdelkafi, N., Makhotin, S., Posselt, T., 2013. Business model innovations for electric mobility - what can be learned from existing business model patterns? Int. J. Innov. Mgt. 17, 1-41.

Abdelkafi, N., Täuscher, K., 2016. Business Models for Sustainability From a System Dynamics Perspective. Organization \& Environment 29, 74-96.

Adams, R., Jeanrenaud, S., Bessant, J., Denyer, D., Overy, P., 2016. Sustainability-oriented Innovation. A Systematic Review. International Journal of Management Reviews 18, 180-205.

Amit, R., Zott, C., 2001. Value Creation in e-Business. Strategic Management Journal 22, 493-520.

Amit, R., Zott, C., 2012. Creating value through business model innovation. MIT Sloan Management Review 53, 41-49.

Arevalo, J.A., Castelló, I., Colle, S. de, Lenssen, G., Neumann, K., Zollo, M., 2011. Introduction to the special issue. Integrating sustainability in business models. Journal of Mgmt Development 30, 941-954. 
Barak, M., Watted, A., Haick, H., 2016. Motivation to learn in massive open online courses. Examining aspects of language and social engagement. Computers \& Education 94, 49-60.

Barlas, Y., 1996. Formal aspects of model validity and validation in system dynamics. System Dynamics Review 12.

Bass, F.M., 1969. A New Product Growth for Model Consumer Durables. Management Science 15, 215-227.

Belleflamme, P., Jacqmin, J., 2016. An Economic Appraisal of MOOC Platforms. Business Models and Impacts on Higher Education. CESifo Economic Studies 62, 148-169.

Bocken, N., 2015. Sustainable venture capital - catalyst for sustainable start-up success? Journal of Cleaner Production 108, 647-658.

Bocken, N., Short, S.W., Rana, P., Evans, S., 2014. A literature and practice review to develop sustainable business model archetypes. Journal of Cleaner Production 65, 4256.

Boons, F., Lüdeke-Freund, F., 2013. Business models for sustainable innovation: state-ofthe-art and steps towards a research agenda. Sustainable Innovation and Business Models 45, 9-19.

Bouwman, H., De Vos, H., Haaker, T., 2008a. Mobile service innovation and business models, in: Mobile Service Innovation and Business Models, pp. 1-327.

Bouwman, H., Zhengjia, M., Van Der Duin, P., Limonard, S., 2008b. Robustness of IPTV business models, in: Mobile Service Innovation and Business Models, pp. 205-216.

Brugmann, J., Prahalad, C.K., 2008. Cocreating business's new social compact. Harvard business review on emerging markets, 173-200.

Brynjolfsson, E., Hu, Y.J., Simester, D., 2011. Goodbye Pareto principle, hello long tail. The effect of search costs on the concentration of product sales. Management science : 
journal of the Institute for Operations Research and the Management Sciences 57, $1373-1386$.

Casadesus-Masanell, $\quad$ R., Kim, H., 2013. Coursera. revised 2015. http://www.hbs.edu/faculty/Pages/item.aspx?num=45248.

Casadesus-Masanell, R., Ricart, J.E., 2011. How to design a winning business model. Harvard Business Review 89, 100-107.

Chesbrough, H., Rosenbloom, R., 2002. The role of business model in capturing value from innovation: evidence from Xerox Corporation's technology spin-off companies. Industrial and Corporate Change 11, 529-555.

Christensen, C.M., 2001. The past and future of competitive advantage. MIT Sloan Management Review 42, 105-109.

Demil, B., Lecocq, X., 2010. Business Model Evolution. In Search of Dynamic Consistency. Long Range Planning 43, 227-246.

Demil, B., Lecocq, X., Ricart, J.E., Zott, C., 2015. Introduction to the SEJ Special Issue on Business Models: Business Models within the Domain of Strategic Entrepreneurship. Strategic Entrepreneurship Journal 9, 1-11.

Doerr, J., Benlian, A., Vetter, J., Hess, T., 2010. Pricing of Content Services - An Empirical Investigation of Music as a Service. AMCIS 2010 Proceedings.

Elkington, J., 1999. Cannibals with forks. The triple bottom line of 21st century business, Paperback ed. Capstone, Oxford.

Fischer, G., 2014. Beyond hype and underestimation. Identifying research challenges for the future of MOOCs. Distance Education 35, 149-158.

Ford, D.N., 1999. A behavioral approach to feedback loop dominance analysis. System Dynamics Review 15, 3-36. 
Forrester, J.W., 1971. Counterintuitive behavior of social systems. [publisher not identified], [Place of publication not identified].

Forrester, J.W., 1976. Urban dynamics, 5. print. MIT Press, Cambridge, Mass.

Hall, J.K., Daneke, G.A., Lenox, M.J., 2010. Sustainable development and entrepreneurship. Past contributions and future directions. Journal of Business Venturing 25, 439-448.

Hamel, G., 2002. Leading the revolution. How to thrive in turbulent times by making innovation a way of life, Fully updated. Plume, New York, NY.

Hart, S.L., Milstein, M.B. Global sustainability and the creative destruction of industries. Smart globalization : designing global strategies, creating global networks.

Hedman, J., Kalling, T., 2003. The business model concept. Theoretical underpinnings and empirical illustrations. Eur J Inf Syst 12, 49-59.

Hew, K.F., Cheung, W.S., 2014. Students' and instructors' use of massive open online courses (MOOCs). Motivations and challenges. Educational Research Review 12, 45 58.

Hockerts, K., Wüstenhagen, R., 2010. Greening Goliaths versus emerging Davids Theorizing about the role of incumbents and new entrants in sustainable entrepreneurship. Journal of Business Venturing 25, 481-492.

Hoxby, C.M., 2014. The economics of online postsecondary education. MOOCs, nonselective education, and highly selective education, Cambridge, Mass.

Hoyt, G., 2014. Economics education in the digital age. The implications of online technologies and MOOCs. The American economic review 104, 514-533.

Huanhuan, W., Xu, L., 2015. Research on technology adoption and promotion strategy of MOOC, in: 6th IEEE International Conference, pp. 907-910. 
Johnson, M.W., Christensen, C.M., Kagermann, H., 2008. Reinventing your business model. Harvard Business Review 86, 50-59.

Jolink, A., Niesten, E., 2015. Sustainable Development and Business Models of Entrepreneurs in the Organic Food Industry. Bus. Strat. Env. 24, 386-401.

Kizilcec, R.F., Schneider, E., 2015. Motivation as a Lens to Understand Online Learners. ACM Trans. Comput.-Hum. Interact. 22, 1-24.

Leckart, S., 2012. The Stanford Education Experiment Could Change Higher Learning Forever. https://www.wired.com/2012/03/ff_aiclass/. Accessed September 29, 2016.

Morecroft, J.D.W., 2015. Strategic modelling and business dynamics. A feedback systems approach, Second edition. John Wiley and Sons Ltd, Chichester, West Sussex, United Kingdom.

Noel, L., Sovacool, B.K., 2016. Why Did Better Place Fail? Range anxiety, interpretive flexibility, and electric vehicle promotion in Denmark and Israel. Energy Policy 94, $377-386$.

Oliva, R., Sterman, J.D., Giese, M., 2003. Limits to growth in the new economy: exploring the 'get big fast' strategy in e-commerce. Syst. Dyn. Rev. 19, 83-117.

Osterwalder, A., 2004. The Business Model Ontology - A Proposition in a Design Science Approach. Dissertation, Lausanne, Switzerland.

Osterwalder, A., Pigneur, Y., 2010. Business model generation. A handbook for visionaries, game changers, and challengers, 1. Aufl. Wiley, Hoboken, NJ.

Pappano, 2012. The Year of the MOOC. http://www.nytimes.com/2012/11/04/education/edlife/massive-open-online-coursesare-multiplying-at-a-rapid-pace.html?_r=0. Accessed September 29, 2016.

Parrish, B.D., 2010. Sustainability-driven entrepreneurship. Principles of organization design. Journal of Business Venturing 25, 510-523. 
PBS Newshour, 2013. How Free Online Courses Are Changing the Traditional Liberal Arts Education. http://www.pbs.org/newshour/bb/education-jan-june13-online_01-08/.

Porter, S., 2015a. The economics of MOOCs: A sustainable future? Bottom Line 28, 5262.

Porter, S., 2015b. To MOOC or not to MOOC. How can online learning help to build the future of higher education? Chandos Publishing is an imprint of Elsevier, Waltham, MA.

Reuver, M., Bouwman, H., MacInnes, I., 2009. Business model dynamics: a case survey. J. theor. appl. electron. commer. res. 4, 1-11.

Reuver, M. de, Bouwman, H., Haaker, T., 2013. Business model roadmapping: a practical approach to come from an existing to a desired business model. Int. J. Innov. Mgt. 17, 1340006.

Rogers, E.M., 2003. Diffusion of innovations, 5th ed. Free Press, New York.

Sánchez, P., Ricart, J.E., 2010. Business model innovation and sources of value creation in low-income markets. European management review : the journal of the European Academy of Management 7, 138-154.

Schaltegger, S., Hansen, E.G., Lüdeke-Freund, F., 2016a. Business Models for Sustainability. Origins, Present Research, and Future Avenues. Organization \& Environment 29, 3-10.

Schaltegger, S., Lu deke-Freund, F., Hansen, E.G., 2016b. Business Models for Sustainability. A Co-Evolutionary Analysis of Sustainable Entrepreneurship, Innovation, and Transformation. Organization \& Environment 29, 264-289.

Schaltegger, S., Lüdeke-Freund, F., Hansen, E.G., 2012. Business cases for sustainability. The role of business model innovation for corporate sustainability. International journal of innovation and sustainable development : IJISD 6, 95-119. 
Schaltegger, S., Synnestvedt, T., 2002. The link between 'green' and economic success. Environmental management as the crucial trigger between environmental and economic performance. Journal of environmental management 65, 339-346.

Schaltegger, S., Wagner, M., 2011. Sustainable entrepreneurship and sustainability innovation. Categories and interactions. Bus. Strat. Env. 20, 222-237.

Seelos, C., 2010. Theorizing and strategizing with models. Generative models of business models. IESE Business School, Barcelona.

Senge, P.M., 1994. The fifth discipline fieldbook. Strategies and tools for building a learning organization, 1. ed. Currency Doubleday, New York.

Smith, M.D., Bailey, J., Brynjolfsson, E., 2002. Understanding digital markets, in: Brynjolfsson, E., Kahin, B. (Eds.), Understanding the Digital Economy: Data, Tools, and Research. MIT Press, pp. 99-136.

Stampfl, G., Prügl, R., Osterloh, V., 2013. An explorative model of business model scalability. International Journal of Product Development 18, 226-248.

Sterman, J., 2000. Business dynamics: Systems thinking and modeling for a complex world. Irwin/McGraw-Hill, Boston, MA.

Sterman, J.D., 2001. System dynamics modeling: Tools for learning in a complex world. California Management Review, 8-25.

Stubbs, W., Cocklin, C., 2008. Conceptualizing a "sustainability business model". Organization and Environment 21, 103-127.

Täuscher, K., Abdelkafi, N., 2015. Business Model Robustness: A System Dynamics Approach, in: Proceedings of 15th EURAM conference. Uncertainty is a great opportunity.

Täuscher, K., Chafac, M., 2016. Supporting business model decisions: a scenario-based simulation approach. Int. J. Markets and Business Systems 2. 
Teece, D.J., 2010. Business Models, Business Strategy and Innovation. Long Range Planning 43, 172-194.

Thompson, J.D., MacMillan, I.C., 2010. Business models: Creating new markets and societal wealth. Long Range Planning 43, 291-307.

Tilley, F., Young, W., 2006. Sustainability entrepreneurs: Could they be the true wealth generators of the future? Greener Management International, 79-92.

Wagner, T.M., Benlian, A., Hess, T., 2014. Converting freemium customers from free to premium. The role of the perceived premium fit in the case of music as a service. Electronic markets : the international journal on networked business 24, 259-268.

Wells, P., 2016. Economies of Scale Versus Small Is Beautiful. A Business Model Approach Based on Architecture, Principles and Components in the Beer Industry. Organization \& Environment 29, 36-52.

Zhang, J., Lichtenstein, Y., Gander, J., 2015. Designing scalable digital business models. Advances in Strategic Management 33, 241-277.

Zott, C., Amit, R., 2007. Business Model Design and the Performance of Entrepreneurial Firms. Organization Science 18, 181-199.

Zott, C., Amit, R., 2008. The fit between product market strategy and business model: implications for firm performance. Strategic Management Journal 29, 1-26.

Zott, C., Amit, R., Massa, L., 2011. The Business Model: Recent Developments and Future Research. JOM 37, 1019-1042. 
Appendix A: Main view of System Dynamics Simulation Model

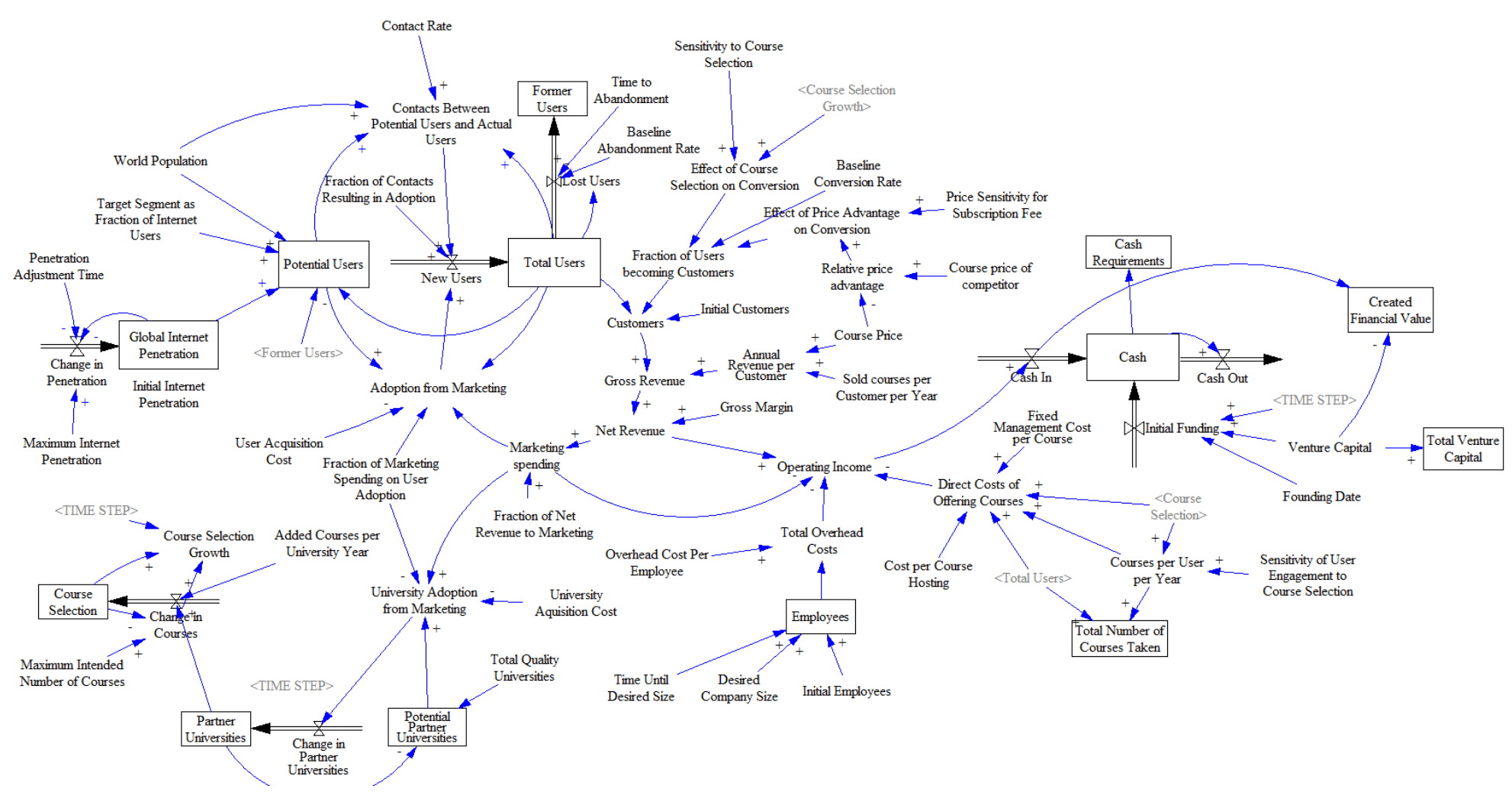

